\title{
Pressure Half Time
}

National Cancer Institute

\section{Source}

National Cancer Institute. Pressure Half Time. NCI Thesaurus. Code C147156.

The amount of time required for the maximum transvalvular pressure gradient to decrease to one half of its initial value. 